\title{
The Relation Between Work and Thumos. A Critical Interrogation of the Motivation Behind Knowledge Work Compulsion
}

\author{
BENDA HOFMEYR \\ Department of Philosophy, University of Pretoria, Lynnwood Rd, Hatfield, Pretoria 0002, South Africa \\ Email: benda.hofmeyr@up.ac.za
}

\begin{abstract}
In this paper I attempt to come to a critical understanding of an intriguing phenomenon at the heart of a broader question, i.e. what are we today - as knowledge workers - in relation to our present understood as the globalising neoliberal governmentality in which life is reduced to constant work under conditions of comprehensive control? Previous attempts to interrogate the nature of knowledge work and the knowledge worker have led me to conclude that these workers do not work to live, but live to work. An important reason seems to be that the neoliberal knowledge worker works all the time because s/he paradoxically wants to. This presents a paradox since the overinvestment in knowledge work does not appear to generate proportionate gains for the working subject. In my attempt to arrive at some kind of explication for this phenomenon of compulsive work, I critically interrogate Fukuyamas contention that work has a thumotic origin. To this end I briefly discuss Plato's conceptualisation of thumos and Hegel's understanding of the significance of labour.
\end{abstract}

Keywords: Fukuyama, Hegel, Plato, thumos, neoliberalism, governmentality, knowledge work, work, labour

\section{INTRODUCTION}

The term 'knowledge worker' was first coined by Peter Drucker in his book, The Landmarks of Tomorrow (1959). The outlines of its current incarnation started to appear in the literature in the subsequent decade (Machulp 1962; Drucker 1969; Bell 1973), took flight thereafter with the neoliberal turn in economic and political thinking, and was catapulted into its various present transmutations with the IT and Internet revolutions. In fact, Soete (2001) contends that the rise of knowledge work as a major trend in Western labour markets is a key factor that distinguishes globally competitive economies from their weaker rivals. The growth of knowledge work reflects a sea change in the mode of capitalist production. Gone are the days of traditional industrial production based on cheap labour and energy and heavy material investments as the primary sources of economic productivity. Now business success relies on improving efficiency defined specifically as the maintenance of 'an unbroken flow of human capability to innovate and embody new ideas and knowledge throughout the economy' 
(Pyöriä 2005: 116-118). Material (matter/energy) outputs have made way for immaterial (information/knowledge) outputs. Unlike the traditional worker, the knowledge worker processes and manipulates information as an end in itself, which means that it is the informational content of the job that defines the task, the product, and ultimately the worker (Schement 1990). As attempts to characterise informational labour have evolved, key characteristics have proven to be a high level of education and skills and the use of information technology (ibid., p. 117).

In the information age, then, knowledge work has become the definitive form of labour that drives economic success. With widespread access to and usage of the Internet as well as interconnected technological capabilities, knowledge work may be performed all the time anywhere. Within this all-encompassing world of work, the knowledge worker finds him/herself working all the time. What one finds is that these workers do not merely work to live, they live to work. Importantly, as Meyer and Allen (1997) point out, knowledge work understood as a 'wanting to work' is an affective commitment. Apart from having to work, and being able to work, knowledge workers want to work. It is a curious phenomenon, because this compulsive working is concomitant with a rise of a host of physical, emotional and psychological disorders as argued by a number of authors (e.g. Verhaeghe 2012; Han 2017), the dissolution of social bonds (Sennett 1998; 2003; 2006) and the absence of any conspicuous correlative gains for the worker. This calls for a critical investigation into the root of the knowledge worker's motivation to want to work incessantly.

Research has shown that employees' commitment to work is directly related to their level of motivation (Yusoff et al. 2013), while what motivates employees has been found to differ markedly between different individuals (Burke 2007; Saraswathi 2011). Herzberg, Mausner and Snyderman's (1959) well known Two Factor Theory distinguished between intrinsic and extrinsic factors. They postulated that extrinsic factors or hygiene factors are necessary to prevent employees' dissatisfaction, but not sufficient to motivate workers. It is motivation factors that increase employee's performance or productivity. This distinction between intrinsic or higher level factors and extrinsic or lower level factors is closely related to Maslow's hierarchy of needs that places intrinsic factors such as recognition and self-actualization above basic needs such as (job) security, pay, benefits, working conditions, etc. In line with Herzberg, Mausner and Snyderman (2010), Drucker (2003) found that knowledge workers are primarily motivated by job quality and content. They are driven by a sense of personal achievement and greater responsibility, which is seen as a sign of recognition. The complex, problem-solving nature of knowledge work indeed lends itself to offer more work satisfaction. However, what these theories fail to unearth is the much more fundamental philosophical dimension that undergirds work motivation. There seems to be some mechanism at work that drives the irrational work-drivenness of the knowledge worker - an ambiguous 'ambition' - a mechanism that neoliberal governmentality succeeds in capitalizing on, but which the cited theories fail to account for.

In order to address this lacuna, the method I employ is a critical, philosophical interrogation with a distinctive sociological slant of Fukuyama's (1992) contention that work has a thumotic origin by assessing it in terms of Plato's conceptualization of thumos in the Phaedrus and The Republic and Hegel's theorization of the significance of work in The Phenomenology of Spirit. This line of research might be situated within the field of critical theory and critical management studies. 


\section{THE NEOLIBERAL RECONCEPTUALIZATION OF HOMO ECONOMICUS}

Han (2017) conceives of the neoliberal working subject as a 'project' rather than a subject. 'As a project deeming itself free of external and alien limitations, the I is now subjugating itself to internal limitations and self-constraints, which are taking the form of compulsive achievement and optimization, writes Han (2017: 15). The model neoliberal subject is homo economicus, but not the classically conceived economic man as a partner in the process of exchange, but as an entrepreneur of himself, 'being for himself his own capital, being for himself his own producer, being for himself the source of [his] earning' (Foucault 2008: 225-226). This is the norm of subject formation that neoliberalism dictates, that sustains neoliberalism, and which it incentivises in turn, since it enables the self not merely to survive but to thrive under neoliberalism. It is a subject identity that is not merely imposed but self-imposed and continuously being remade to become ever more efficient through constant self-investment. Subjugation, then, is attended by a powerful sense of autonomy and becomes self-subjugation.

Hence the neoliberal subject is caught in a double-bind. The subject's identity is the very condition of possibility of the subject's being, but also the source of its subjection. It therefore cannot simply be discarded without destroying the very self. Refashioning one's subject identity as a form of resistance poses the very real risk of 'creative destruction' however, i.e. remoulding the old to make room for an even better capitalist innovation in the service of the market as opposed to an act of securing a measure of freedom from it.

What is at the heart - or rather soul - of this ambiguous ambition that propels the knowledge worker's work-drivenness despite its evident costs and the fact that the knowledge worker is not motivated by more money? Among the ancients, we find what Nietzsche might have called the Entstehungsherd (place of emergence) of the idea that along with reason and desire, there is something like an innate human spiritedness. It is this 'spiritedness' that may account for the spawning of an irrational drive to live in order to work in the ambitious knowledge worker. It is well known that it was Fukuyama (1992) who argued that labour has its origin in the ancient spiritedness that the Greeks called thumos (also commonly spelled 'thymos'; Greek: $\theta u \mu$ ó $)$. The notion of thumos may be traced back to Plato.

\section{THUMOS IN PLATO}

In the Phaedrus Plato (c. 370 BC) postulates that the soul has three component parts, which he explicates by way of Socrates's allegory of the chariot. In the allegory, a chariot (representing the soul) is pulled by a rebellious dark horse, which symbolizes man's appetites or desires, and a high-spirited white horse, which symbolizes thumos. The charioteer is Reason. Reason's challenge is to harness the energy of both horses, getting the divergent steeds - that 'pull it (the chariot or the soul) violently in different directions' ( $\$ 248 \mathrm{a}$ ) - into sync to be able to successfully pilot the chariot into the heavens where he can behold Truth and become like the gods. The soul's fate is therefore dependent upon the establishment of a symbiotic cooperative relationship between the appetites and desires ${ }^{1}$, on the one hand, and thumos, on the other. In the Phaedrus, the noble white horse is described as 'a lover of honor and modesty and self-control; companion to true glory' ( $\$ 253 \mathrm{e}$ ), while no explicit mention is made of thumos as in The Republic.

\footnotetext{
1 'Desire' is himeros: the derivation is from merē (particles), ienai ('go') and rhein ('flow').
} 
In The Republic, thumos refers to the spiritedness with which we rise to the defence of someone or something that we hold dear and cherish; the willingness even to sacrifice oneself in defence of that someone especially if s/he cannot defend themselves. This desire is especially aroused in the face of injustice. In other words, thumos is the well-spring of righteous indignation, which leads to anger, which in turn gives rise to the desire for vengeance. It is what drives Achilles' constant struggle for glory, retribution and vengeance in Homer's The Iliad. It is what incites Antigone to bury her brother in defiance of what she views as the intolerable injustice of Creon's refusal to grant him a proper burial. In The Republic, the guardians are the gatekeepers of justice in the polis (city-state) $(\$ 375 \mathrm{a}-356 \mathrm{c})$. The guardians are naturally endowed with 'an invincible and unbeatable spirit' ( $\$ 375 b)$. To be able to do so, they must be quick to anger, ready to fight and victory-loving, so as to be willing to sacrifice their own good in defence of their polis and their fellow citizens. However, Socrates recognizes that this spiritedness, left to its own devices, might lead to injustice. Thus it must be balanced by gentleness acquired through philosophical education so as to acquire wisdom or the art of discernment and restraint when required. The dilemma, which Socrates recognizes, is that thumos is both a necessary condition for the possibility of justice and poses a fundamental challenge to it. Nature has to be augmented by nurture, that is, only the education of the guardians can adequately restrain the thumotic element in the polis, and ensure that the guardians remain allied to the rationally calculating element in the polis, the rulers, and thus be gentle to all the other citizens, while being fierce towards enemies of the polis. Importantly, then, Plato believed that thumos was the source of a host of traits such as bravery, determination, and the need for justice. Unlike the violent, self-destructive thumos of Homeric epics, Plato's idea of thumos was tempered by a need for civility and order.

On Fukuyama's reading of Kojeve's interpretation of Hegel, Hegel postulated that work is motivated by this 'energy', thumos, that drives us forward and keeps us working even if the passions dictate otherwise.

\section{THE THUMOTIC ORIGIN OF WORK?}

Fukuyama (1992: 225) reminds us that traditional liberal economic theory, spearheaded by Adam Smith, contends that work is an essentially unpleasant activity undertaken for the sake of the utilities of the things created by work. That utility can be enjoyed primarily in leisure. In a certain sense then, what motivates people to work is the prospect of the opportunities work creates for not working, i.e. leisure. The motivation to work, so it is theorised, is determined by a rational cost-benefit analysis: the utility of the material benefit arising out of work and the leisure it affords must exceed the disutility of work such as long working hours, sacrifice of family time, etc. According to traditional liberal economic theory then, reason and desire suffice to account for the differing propensities to work. When it comes to the compulsively working knowledge worker, however, this explanation falls short since their motivation to work does not correlate with their consumption patterns of leisure time. Fukuyama argues that the notion of work ethic implies that the degree to which people work is related to culture and custom, and hence related to thumos (ibid.). Here he connects the motivation to work ethic, that, as a cultural conditioned phenomenon, he then ascribes to thumos. From a Platonic point of view, however, thumos might come into play when it comes to work ethic, but precisely because work ethic is culturally conditioned, the motivation to work as such cannot be ascribed to it as cause, since work ethic is a relatively recent historical phenomenon. Thumos, on 
the other hand, is a universal innate component of the soul. The history of the work ethic does indeed testify to the fact that an over-investment in work is not strictly related to compensation, and hence irrational from a strictly utilitarian point of view. Fukuyama cites the examples of the contemporary 'type-A' personality - the hard-charging lawyer or corporate executive, or the Japanese 'salaryman' employed by a competitive Japanese multinational corporation that easily works 70 or $80 \mathrm{~h}$ per week, with few or short holidays:

They work so hard that they are never able to make use of their money; they cannot enjoy their leisure because they have none; and in the process they ruin their health and their prospects for a comfortable retirement, because they are likely to die sooner (ibid.).

While I agree with Fukuyama that workaholics clearly derive satisfaction from the work itself, or the status and recognition that it provides (ibid., p. 226), in critically assessing the hypothesis of the thumotic origin of work, I am not so much interested in the miniscule fraction of the working population that has a certain personality type or belongs to cultures in which a strong work ethic is instilled, that fraction of the workforce that is operative at the pinnacle of the capitalist economy in high-flying, high-pressure and high-earning jobs. What I am interested in is what motivates the much more prevalent knowledge worker in the Information Age to ceaselessly plough his/her attention and time into work. Elsewhere I have argued that while the neoliberal knowledge worker has a meaningful and fulfilling job, given its challenging and problem-solving nature, it is all-absorbing. Connected mobile smart technologies have displaced work out of the office and beyond any traditional working hours into every remote recess of personal and private life. A case in point is the fact that the oxymoronic notion of a 'working-holiday', which is strictly speaking a contradiction in terms, has become common parlance and practice. Instead of recognizing the worrisome invasion of work into leisure time, the neoliberal knowledge worker embraces the introduction of leisure into constant working time. For all the freedom the knowledge worker enjoys, s/he remains subject to an economic rationality that dictates ever-increasing efficiency. The neoliberal knowledge worker may as a result be typified as single-focused - even while multi-tasking - which is the direct result of the invasion of work into private life. In other words, amidst the array of everyday life responsibilities and activities, the knowledge worker is in actual fact cognitively preoccupied with the problem-solving task of the day and armed with smart connected devices that either 'zooms' the worker to work, or insinuates work and managerial control into the home, the car, the supermarket, or wherever the private routines of the day take the worker. Given the fact that knowledge work has become the most decisive driver of the economy, it might be contended that an ever-increasing segment of the workforce is in actual fact living for the sake of work - albeit unwittingly - as opposed to working to live. Moreover, this overinvestment in work does not seem to correlate with any increase in quality of life. While quality of life defies exact measurement on account of the diverse meanings it holds for individuals, this overinvestment does not appear to correlate with a proportionate increase in utility. There appears to be no perceptible increase in the well-being of the industrious knowledge worker. What we have seen instead is an arresting rise in mental and physical disorders (Verhaeghe 2012; Han 2017). Social theorists like Bourdieu (1998), Boltanski and Chiapello (2007) and Sennett (2006) have documented the demise of collective bonds as a result of the rise of a kind of narcissistic self-aggrandizement in the face of the neoliberal governmentality that prizes competition even in cooperation, and individualization even in the context of teamwork. Boltanski and Chiapello specifically emphasise 
the new capitalism's network-based form of organization founded on employee initiative and autonomy in the workplace, which they describe as a putative freedom bought at the cost of material and psychological security, and resulting in a more successful, pernicious and subtle form of exploitation.

Why, then, does the neoliberal worker want to work all the time? Does the contention that the motivation to work is rooted deep in the human psyche as a fundamental ontological drive of sorts that works together - although not necessarily in consort - with reason and desire, hold compelling explanatory power? For Plato, to be sure, it is indeed the white horse of thumos that compels us to pursue honour, but also modesty and self-control as opposed to blind ambition or self-aggrandizement. He conceives of thumos as the seat of righteous indignation in the face of injustice that causes harm to those one holds dear, and hence the guardian of collective bonds not their death knell. The quick temper and readiness to fight of the guardians seated in their thumos were always in the service of maintaining justice in the polis. To prevent the excess to which the powerful spiritedness is naturally prone, Socrates advised that it must be balanced by gentleness acquired through philosophical education so as to instil wisdom, that is, the art of discernment that recognizes the need for restraint when required. Plato's notion of thumos is not the brutal rage that led to the self-destruction of the majority of the heroes of Homeric epics, but the well-spring of bravery, tenacity and the need for justice. From the Platonic perspective, it seems at least plausible that thumos accounts for the irrational work-drivenness of neoliberal knowledge workers. It is a work-drivenness that is not in the service of merely satisfying the desires and appetites, and which, if left unbridled, atrophies into deplorable vices such as the blind ambition to do whatever it takes, at whoever's expense, to get ahead. However, does it also explain why the average neoliberal knowledge worker inadvertently live for the sake of work?

Admittedly, knowledge workers work all the time because they are subject to immense pressure to perform and deliver, but as Han (2017: 34) points out, power that functions through coercion does not represent power of the highest order. 'The greater power is, the more quietly it works. It just happens: it has no need to draw attention to itself.' In fact, today 'power is assuming increasingly permissive forms. In its permissivity - indeed, in its friendliness - power is shedding its negativity and presenting itself as freedom' (ibid., p. 35). This is a crucial insight, since it means the free working subject has internalized the injunction to work. As something that emanates from within the working subject, the worker is not pushed and pulled to work through compulsion, but driven by conviction. However, the unquestioned wholesale conviction displayed by the ever-working subject even in the face of the evident toll it takes, cannot entirely be accounted for by the clever charade of other-induced coercion masking as self-motivated conviction. The inherent contradictions of the irrational, obsessive and self-destructive work-drivenness are inevitably bound to result in severely detrimental side-effects for the working subject and it does. On both the rational and the emotional levels, the working subject is bound to become disenchanted by the clever ploy of 'smart power'. Despite the havoc it wrecks on the working subject's mental and physical health, on collegial and familial relationships, the knowledge work addict displays an almost devotional commitment to the task at hand. To be sure, the neoliberal workplace lends a hand by way of extensive wellness programmes to mitigate the destructive effects of an overinvestment in work. However, 'managing the side-effects' also cannot wholly account for the worker's steadfastness. 


\section{THE SIGNIFICANCE OF WORK IN HEGEL}

No equivalent term exists in English that encompasses the scope of what thumos signified for the Greeks. If no exact translation exists for an ideal, it might be taken to mean that ideal does not exist within a particular society. If one accepts the Platonic postulation of thumos as a fundamental ontological drive, that, along with reason and desire, constitutes the third component part of the soul, how can it not exist in a society? One could speculate that the values, characteristics and actions that spring from thumos are either wrongfully attributed to reason or desire, or actively suppressed so as to go unrecognized or unaccounted for. Given the fact that the model neoliberal citizen that thrives in the Information Age is marked by characteristics such as fierce ambition, industriousness, entrepreneurial ingenuity and steadfastness even in the face of impossible odds, it seems implausible that thumos does not exist or is actively suppressed in contemporary society.

Classical economists have ascribed the motivation to work to wages earned. More generally, it is taken for granted that increased earnings serve to satisfy our desires and appetites. We work, in other words, to appease the dark horse, and reason, the charioteer, is tethered to its insatiable appetite.

The salient role of an economic rationality and the persistence of materialism among consumers under neoliberalism are not in question. What is, is whether or not reason and desire have supplanted thumos as the motor force of work. While there is no such thing as an irrational thumotic drive to be found in Hegel's theorization of labour in the Phenomenology of Spirit [ $\$ 178-\$ 230]$, the significance he attributes to labour ${ }^{2}$ may justifiably be ascribed to a thumotic origin when read through a Platonic lens. If the ego attains full self-consciousness through the reciprocity of perspectives in self-consciousness, and finally universality through participation in ethical and cultural life, and labour is the vehicle, then labour is not merely a means, but the very being of the labourer. He comes to realize that it is his labour that creates the world and enables it to function. Work, for Hegel, is a central life-activity. Work is the means through which the labourer becomes 'self-actualized'. The fruits of the worker's labour are the life-affirming definition of his/her very being. In Hegel, it is the labourer that transforms labour into the appropriate medium for his/her own self-development, but these shaped objects that become commodities exchanged on the market are also the means through which the labourer is recognized by others. In his/her work, the labourer sacrifices him/herself and in doing so - precisely by doing so - s/he receives back from it his/her own self.

Hegel's conception of civil society that separates the political from the civil brought the centrality of 'the economy' or state-wide 'household' - the sphere of the majority working to earn a living reside - to his attention. Concerning labour and the labourer it brings with it two problems: the first concerns alienation. The labourer finds him/herself in his/her work as well as a sense of mutual recognition, but s/he also finds him/herself at the mercy of a system of exchange over which s/he has no control. Hence, the shadow side of labour entails alienating and dehumanizing effects that have been greatly amplified by the capitalist system's unfettered markets.

2 In the explication of the lord-bondsman dialectic offered here I am indebted to Paul Ashton's 1999 talk at the 'Legacy of Hegel' seminar held at the University of Melbourne on 5 February 1999. Available online: https://www.marxists.org/reference/archive/hegel/txt/ashton.htm 
The second problem related to labour that Hegel foregrounds is poverty - poverty not only of the body but also of the mind. Hegel recognizes the rise of poverty on account of overproduction due to the use of machine labour and competition. Even more fundamentally, one's very spirit becomes impoverished when your need to identify with your central life-activity, work and with the broader community goes unfulfilled.

Hegel, then, maintains that work is not merely an economic activity or something we do to survive. For him, work is the most important activity in the development of self-conscious freedom. As such, it is entirely tenable that work is rooted in thumos - that which drives the self forward in its quest for recognition and flourishing. Thumos covers qualities such as courage, determination, spirit, enterprise and ambition; a self-regarding instinct of sorts that ranges from self-assertion, through self-respect, to our relations with others. All of these dimensions are encapsulated in Hegel's conceptualization of labour.

\section{CONCLUSIONS}

We may conclude, then, that read through a Platonic lens, it is thumos - not primarily reason or desire - that fuels the worker to work, and knowledge work in particular - as challenging, entrepreneurial, creative and problem-solving - ignites the thumotic dimension of the soul. It is what spurs the worker on to action and to keep at it until the job is done. It is unsurprising then that the neoliberal knowledge worker's work-drivenness is irrational from a utilitarian point of view, i.e. that the surplus gains for the workaholic is not necessarily evident in conspicuous consumption or increased health or well-being. Work, it would seem, appeases not the dark horse of desire, but the white stallion of thumos, what Empedocles called the 'seat of life' - the part of the soul that seeks recognition and honour over security.

Received 21 May 2021

Accepted 2 July 2021

\section{References}

1. Bell, D. 1973. The Coming of Post-industrial Society. A Venture in Social Forecasting. New York: Basic Books.

2. Boltanski, L.; Chiapello, E. 2007. The New Spirit of Capitalism. Trans. G. Elliot. London: Verso.

3. Bourdieu, P. 1998. 'The Essence of Neoliberalism' in Le Monde diplomatique, trans. J. J. Shapiro. Available at: https://mondediplo.com/1998/12/08bourdieu

4. Burke, R. 2007. Project Management Leadership. Cape Town: Burke.

5. Drucker, P. F. 1959. Landmarks of Tomorrow: Report on the New Post-modern World. New York: Harper \& Row.

6. Drucker, P. F. 1969. The Age of Discontinuity: Guidelines to Our Changing Society. London: Heinemann.

7. Drucker, P. F. 2003. On the Profession of Management. US: Harvard Business Review.

8. Foucault, M. 2008. The Birth of Biopolitics. Lectures at the Collège de France, 1978-79. Trans. G. Burchell. New York: Palgrave Macmillan.

9. Fukuyama, F. 1992. The End of History and the Last Man. New York: The Free Press.

10. Han, B.-C. 2017. Psychopolitics: Neoliberalism and New Technologies of Power. London: Verso.

11. Hegel, G. W. F. 1979 (1807). Phenomenology of Spirit, Trans. A. V. Miller. Oxford: Clarendon Press.

12. Herzberg, F.; Mausner, B.; Snyderman, B. B. 2010. The Motivation to Work. London: Transaction Publishers.

13. Machulp, F. 1962. The Production and Distribution of Knowledge in the United States. Princeton, NJ.: Princeton University Press.

14. MacIntyre, A. 1988. Whose Justice? Which Rationality? Ducksworth: University of Notre Dame Press.

15. Maslow, A. 1943. 'A Theory of Human Motivation', Psychological Review 50(4): 370-396.

16. Meyer, J. P.; Allen, N. J. 1997. Commitment in the Workplace: Theory, Research and Application. CA: Sage.

17. Plato. 1968. The Republic. Trans. A. Bloom. New York: Bloom.

18. Plato. 2008 (circa 370 BCE). Phaedrus. Trans. B. Jowett. The Project Guttenberg Ebook. 
19. Pyöriä, P. 2005. 'The Concept of Knowledge Work' Journal of Knowledge Management 9(3): 116-127.

20. Saraswathi, S. 2011. 'A Study on Factors that Motivate IT and Non-IT Sector Employees: A Comparison', International Journal of Research in Computer Application and Management 1(2): 72-77.

21. Schement, J. R. 1990. 'Porat, Bell, and the Information Society Reconsidered: the Growth of Information Work in the Early Twentieth Century', Information Processing \& Management 26(4): 449-465.

22. Sennett, R. 1998. The Corrosion of Character: The Personal Consequences of Work in the New Capitalism. New York: Norton.

23. Sennett, R. 2003. Respect in a World in Inequality. New York: Norton.

24. Sennett, R. 2006. The Culture of the New Capitalism. New Haven: Yale University Press.

25. Soete, L. 2001. 'ICTs, Knowledge Work and Employment: the Challenges to Europe', International Labour Review 140(2): 143-163.

26. Verhaeghe, P. 2012. What Abour Me? The Struggle for Identity in a Market-based Society. Trans. J. HedleyPrôle. London: Scribe.

27. Yusoff, W. F. W.; Kian, T. S.; Idris, M. T. M. 2013. 'Herzberg's Two Factors Theory on Work Motivation: Does it Work for Today's Environment?', Global Journal of Commerce \& Management Perspective 2(15): $18-22$.

BENDA HOFMEYR

\title{
Santykis tarp darbo ir thymos. Kritinè motyvacijos priverstiniam žinojimo srities darbui analizè
}

\begin{abstract}
Santrauka
Straipsnio tikslas - pasiekti kritini supratimą intriguojančio reiškinio, suteikiančio pagrindą platesniam klausimui: Kas mes - žinojimo srities darbuotojai (knowledge workers) - šiandien esame, žvelgiant iš dabartinès globalaus neoliberalaus valdymo perspektyvos, redukuojančios gyvenima i nuolatinį darba visapusés kontrolès sąlygomis? Ankstesni straipsnio autoriaus bandymai ištirti žinojimo srities darbo ir minètos srities darbuotojo prigimtị leido prieiti prie išvados, kad šie darbuotojai dirba ne tam, kad gyventų, bet gyvena tam, kad dirbtų. Autoriaus manymu, svarbi anksčiau nurodyto fakto priežastis yra ta, kad žinojimo srities darbuotoja / darbuotojas dirbą visą laiką, nes ji / jis paradoksaliai to nori. Tai tikras paradoksas, kadangi paaiškẻja, jog per didelès investicijos ị žinojimo srities darbą pačiam dirbančiajam neatneša jas atitinkančios naudos. Siekdamas paaiškinti ši priverstinio darbo reiškinį, straipsnio autorius pateikia kritinę F. Fukuyama’os pozicijos analizę, kuri teikia tiumotinę (sen. gr. thymos - karštas noras, siekimas, aistra, poreikis, garbès troškimas) darbo kilmę. Autorius trumpai aptaria Platono pateiktą thymos principo sampratą ir G. W. F. Hegelio darbo reikšmingumo koncepciją.
\end{abstract}

Raktažodžiai: Fukuyama, Hegelis, Platonas, thymos, neoliberalizmas, valdymas, žinojimo srities darbas, darbas, triūsas 